\title{
PENERAPAN METODE QUANTUM WRITER UNTUK MENINGKATKAN KEMAMPUAN MENULIS PUISI PADA SISWA SMK TELEKOMUNIKASI DARUL'ULUM
}

\author{
Dinike Agustin Puteri \\ SMK Telekomunikasi Darul'Ulum \\ Jl. Rejoso, Ponpes Darul'Ulum, Peterongan, Jombang, Indonesia \\ Pos-el : dinikeagustinp@yahoo.com
}

\begin{abstract}
Quantum Writer method is good way to help student more easy and attractive to write. Quantum Writer method is contains four steps teaching learning writing ang can be easy to with PAK! namely: concentrate $(P)$, arrange $(A)$, composing $(K)$, the best (!). This method used to finished that problem appear (1) How to proces learning poerty at begining with Quantum Writer method, (2) How to proces learning poerty when student is writing poerty with Quantum Writer method, (3) How to proces learning poerty at the finishing or after writer poerty with Quantum Writer method, in this case every statement of the problem given student score. This Action Research (PTK) used descriptive kealitatif method is doing two steps is that observation student SMK Telekomunikasi Darul'Ulum. The data take from pre writing is contain students ability to mention theam. Then the result take from when student is writing poerty. With Quantum Writer merhod. Second step is that finished to write the result contains are reading a poerty, give suggestion with friend's poetry, and revisi again based on friend's suggestion. The result of the observation is that appliying Quantum Writer writer method can be increase to writing poetry very good for student. Students ability to writing poetry more increase every steps. And the response of the student increase.
\end{abstract}

Keywords: write poetry, quantum writer method

\begin{abstract}
ABSTRAK
Metode Quantum Writer merupakan alternatif yang tepat untuk membantu siswa agar lebih mudah mengawali menulis dan dapat menulis dengan mudah dan menyenangkan. Metode Quantum Writer adalah metode yang memuat empat langkah pembelajaran menulis, yang terangkum dalam istilah PAK!, Yaitu: pusatkan pikiran (P), atur (A), karang (K), dan hebat (!). Metode ini dipergunakan untuk memecahkan rumusan masalah yang ada yakni (1) Bagaimana proses pembelajaran puisi pada tahap pra menulis dengan metode Quantum Writer, (2) Bagaimana proses pembelajaran puisi pada tahap saat menulis dengan metode Quantum Writer,
\end{abstract}


(3) Bagaimana proses pembelajaran puisi pada tahap pasca menulis dengan metode Quantum Writer, yang di dalam setiap rumusan masalah tersebut terdiri dari penilaian produk dan penilaian hasil. Penelitian Tindakan Kelas (PTK) ini menggunakan metode Deskriptif kualitatif yang dilakukan melalui dua siklus dengan subyek penelitian Siswa SMK Telekomunikasi Darul'Ulum Jombang. Data diambil dari tahap pra menulis yang terdiri dari penilaian proses yang berupa afektif siswa dan penilaian produk yang berupa kemampuan siswa dalam menyebutkan tema. Tahap saat menulis yang terdiri dari penilaian proses yang berupa afektif siswa dan penilaian produk yang berupa hasil penilaian menulis puisi siswa dengan metode Quantum Writer. Tahap pasca menulis, yang terdiri dari penilaian proses yang berupa penilaian afektif siswa dan penialain produk yang berupa penilaian pembacaan puisi, memberikan komentar terhadap puisi teman, dan merevisi puisi berdasarkan komentar teman. Hasil penelitian menunjukkan bahwa penerapan metode Quantum writer dapat meningkatkan keterampilan menulis puisi siswa. Kemampuan siswa menulis puisi terus meningkat pada setiap siklus. Begitu juga respon atau afektif siswa terus meningkat pada setiap siklus.

Kata Kunci : Menulis Puisi, Metode Quantum Writer

\section{PENDAHULUAN}

Pembelajaran bahasa Indonesia di lembaga pendidikan, di setiap jenjang pendidikan diajarkan melalui mata pelajaran Bahasa Indonesia. Pembelajaran bahasa Indonesia mencakup 4 aspek, yaitu keterampilan membaca, menulis, berbicara, dan menyimak. Keterampilan menulis sama halnya dengan kemampuan berbahasa lainnya, dapat dimiliki melalui bimbingan dan latihan yang intensif.

Untuk menunjang keberhasilan tujuan umum pembelajaran bahasa Indonesia, maka siswa harus terampil dalam bahasa yang mencakup aspek mendengarkan, berbicara, membaca, menulis dan apresiasi sastra. Dari semua aspek keterampilan berbahasa tersebut, aspek keterampilan menulis merupakan aspek yang paling tinggi dan paling kompleks tingkatannya, faktor yang menjadi penyebab hal tersebut diantaranya karena siswa lebih suka untuk menikmati karya tulis yang sudah ada dari pada menciptakan karya tulis baru, siswa kurang mampu untuk menuliskan apa yang ada diangan angan mereka ke dalam bentuk tulisan, siswa cenderung merasa malas untuk menulis.

Menulis keterampilan menemukan atau melukiskan lambang-lambang grafik yang menggambarkan suatu bahasa yang dipahami oleh seseorang, sehingga orang lain dapat membaca lambanglambang tersebut kalau mereka memahami bahasa dan gambaran grafik itu (Tarigan, 2015:254). Menulis akan memberikan beberapa manfaat bagi seseorang, diantaranya: (1) Mengenali diri, (2) Mengevaluasi diri, (3) Menikmati kebebasan menulis, (4) Berdialog dengan diri, (5) Menulis 
untuk berefleksi (Hernowo, 2009:7). Dari manfaat-manfaat tersebut diharapkan akan muncul potensi menulis dari dalam diri seseorang. Meskipun keterampilan menulis dianggap sebagai keterampilan yang sulit dan rumit tetapi keterampilan menulis itu sangatlah penting untuk dipelajari dan dilakukan terus-menerus. Keterampilan menulis harus didukung juga oleh keterampilan lainnya terutama keterampilan membaca, karena membaca dan menulis saling berkaitan. Berdasarkan Kurikulum 2013, pelajaran menulis puisi mendapat perhatian yang lebih banyak karena selama ini siswa mengalami kesulitan untuk menuangkan pemikiran serta ide-ide mereka ke dalam suatu bentuk tulisan, yakni sebuah puisi. Sebenarnya Siswa mempunyai kesempatan untuk mengaplikasikan ke dalam bentuk karya nyata yang memiliki nilai tinggi, hanya saja siswa tidak mampu untuk mengoptimalkan kemampuan mereka, tentunya hal tersebut tak terlepas dari peran serta seorang guru sebagai seorang pendidik. Selama ini metode yang dipergunakan oleh seorang guru dalam pembelajaran dapat dikatakan kurang efektif, guru- guru cenderung menerapkan metode ceramah dalam setiap pembelajaran di kelas. Hal ini berimbas pula terhadap pola pikir dan keberhasilan siswa dalam mencapai prestasinya.

Pembelajaran bahasa Indonesia yang mencakup kemampuan menulis diajarkan diantaranya melalui menulis puisi. Menulis puisi bukan merupakan pekerjaan yang mudah. Siswa sering mengeluh ketika membuat suatu puisi. Mereka lebih suka membaca dari pada membuat suatu hasil karya, yaitu puisi. Puisi merupakan peluapan spontan dari perasaan-perasaan yang penuh daya; dia bercakal bakal dari emosi yang terpadu kembali dalam kedamaian (Tarigan, 2011:28). Puisi sebagai wadah inspirasi dalam mengurangi kehidupan dapat memberikan warna tersendiri dari luapan emosi, perasaan hati baik ungkapan suka maupun duka yang diwujudkan dalam bentuk tulisan dan bersifat imajinatif. Menulis puisi sama dengan bermain dengan kata, bahasa, dan makna karena menulis puisi penulis mengaplikasi kata-kata dengan tepat sehingga kata tersebut menjadi padat dan bermakna. Tapi tidak semua orang dapat mengungkapkan isi hati, inspirasi, dan luapan emosinya dalam bentuk puisi.

Guru harus bisa membuat cara untuk meningkatkan kemampuan menulis puisi bahasa Indonesia siswa. Pembelajaran tersebut harus disesuaikan dengan karakteristik remaja. Menyadari betapa pentingnya keterampilan menulis bagi siswa yang tercantum pada mata pelajaran Bahasa dan Sastra Indonesia pada setiap jenjang pendidikan dasar sampai pendidikan menengah atas, maka penulis beranggapan yang harus dilakukan sekarang ini peningkatan kemampuan menulis selanjutnya

Menyadari betapa pentingnya keterampilan menulis bagi siswa yang tercantum pada mata pelajaran Bahasa dan Sastra Indonesia pada setiap jenjang pendidikan mulai pendidikan dasar Dinike Agustin Puteri, Variasi Bahasa.............. (91-99) 
sampai pendidikan menengah atas, maka penulis beranggapan yang harus dilaksanakan sekarang ini peningkatan kemampuan menulis selanjutnya.

\section{Masalahnya di SMK} Telekomunikasi Darul'Ulum, siswa kurang mampu untuk menulis sebuah karya puisi, mereka cenderung lebih senang untuk membaca puisi. Metode yang ditampilkan oleh guru mereka cenderung monoton, yakni dengan metode ceramah. Hal ini menjadikan siswa kurang bergairah dalam materi menulis puisi, serta penggunaan media dalam pembelajaran juga bisa dikatakan masih kurang maksimal, guru kurang bisa mengoptimalkan media-media yang terdapat di lingkungan sekitar. Akibatnya nilai mereka pada aspek menulis puisi menjadi rendah, hal ini terlihat dari survei awal yang dilakukan oleh peneliti, dari sejumlah siswa diberikan tugas untuk membuat puisi dengan tema bebas, setelah dilakukan penilaian dan evaluasi ternyata masih banyak siswa yang belum mampu untuk menulis sebuah puisi, nilai yang mereka tunjukkan pun dibawah Kriteria Ketuntasan Minimal. Untuk itu diperlukan suatu penggunaan pendekatan, media dan metode yang tepat, sehingga cenderung guru yang aktif dan siswa pasif. Tugas utama guru adalah mengelola interaksi belajar mengajar, yakni kemampuan mendesain program dan keterampilan mengkomunikasikan program itu kepada peserta didik (Sardiman, 2007:63). Interaksi tersebut sudah barang tentu akan mengoptimalkan pencapaian tujuan yang dirumuskan.

Untuk itu dalam pembelajaran diperlukan metode yang sesuai dengan tingkat perkembangan siswa. Dengan demikian pemilihan metode yang tepat dan efektif sangat diperlukan. Sebagaimana pendapat (Hamalik, 2008:184), bahwa peranan metode mengajar sebagai alat untuk menciptakan proses belajar dan mengajar sehingga dapat merangsang minat belajar siswa. Quantum Writer merupakan salah satu cara membelajarkan siswa yang digagas oleh Potter. Melalui Quantum Writer siswa akan diajak belajar dalam suasana yang lebih nyaman dan menyenangkan, sehingga siswa akan lebih bebas dalam menemukan berbagai pengalaman baru dalam belajarnya. Dalam hal ini metode Quantum Writer dapat digunakan sebagai suatu cara yang tepat untuk membantu siswa meningkatkan keterampilan menulis. Teknik ini tepat diterapakan pada semua pembelajaran menulis. Deporter (2009:13) menyatakan bahwa metode Quantum Writer bisa digunakan pada tulisan manapun-esai formal, presentasi, renungan pribadi, laporan, pesan e-mail, cerita, artikel, buku, dan sebagainya. Dengan metode ini diharapkan akan dapat membantu siswa dan guru untuk memecahkan persoalan yang terjadi selama proses belajar mengajar yang mengacu pada materi menulis puisi, sehingga siswa tidak akan merasa sukar ketika menulis sebuah puisi. 


\section{METODE PENELITIAN}

Penelitian ini menggunakan Desain Penelitian Tindakan Kelas Model Kurt Lewin. Model Kurt Lewin menjadi acuan pokok atau dasar dari adanya berbagai model penelitian tindakan kelas lainnya, khususnya PTK karena Kurt Lewin adalah orang pertama yang memperkenalkan Action Research atau penelitian tindakan.
Konsep pokok penelitian tindakan Model Kurt Lewin terdiri atasa empat komponen yaitu; a) perencanaan (planning), b) tindakan (acting), c) pengamatan (observing), dan refleksi (reflecting). Hubungan keempat komponen tersebut dapat digambarkan sebagi suatu siklus seperti berikut:

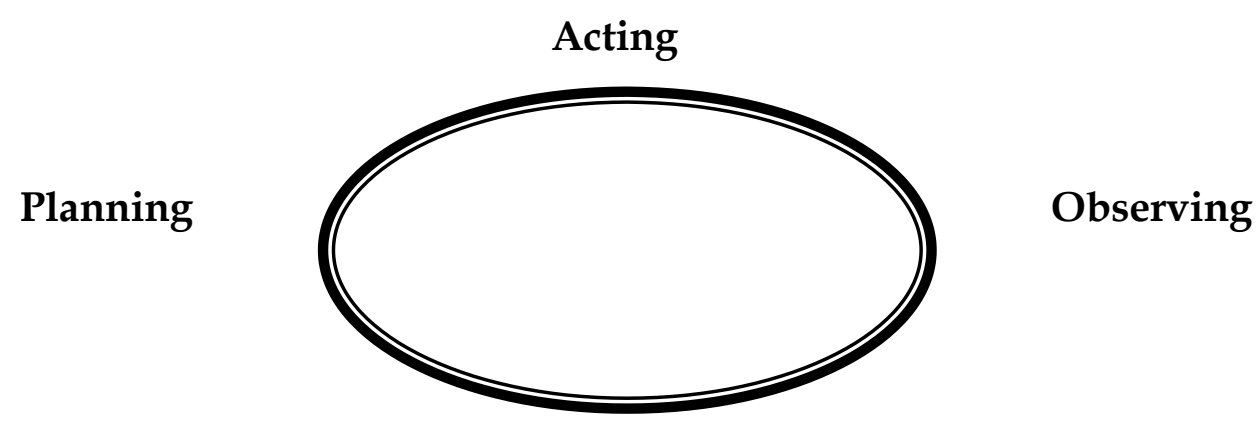

Disain PTK Model Kurt Lewin

(Susili, Herawati, Chotimah, Khusnul\&Dwita, Yuyun Sari. 2009)

\section{HASIL DAN PEMBAHASAN}

Penyampaian materi pelajaran Bahasa dan Sastra Indonesia perlu dirancang suatu strategi pembelajaran yang tepat, yakni anak akan mendapatkan pengalaman baru dalam belajarnya, selain itu siswa akan merasa nyaman. Dengan menerapkan Quantum Writer, maka dalam mengusahakan pembelajaran yang menyenangkan bagi siswa dan meningkatkan kualitas pembelajaran Bahasa Indonesia di pendidikan dasar dapat tercapai. Selain itu juga dapat memperbaiki penerapan kurikulum saat ini dan meningkatkan pemahaman serta menciptakan suasana belajar yang kondusif.
Pada saat pembelajaran Bahasa Indonesia disebutkan bahwa fungsi metode mengajar dalam keseluruhan sistem pengajaran adalah sebagaimana alat untuk mencapai tujuan pengajaran. Metode Quantum Writer sebagai salah satu alternatif dalam pembelajaran Bahasa Indonesia yang membawa siswa belajar dalam suasana yang lebih nyaman dan menyenangkan, serta memberdayakan siswa dalam mengasah kemampuan menulis puisi. Siswa akan lebih bebas dalam menemukan berbagai pengalaman baru dalam belajarnya, sehingga diharapkan dapat tumbuh berbagai kegiatan belajar siswa.

Quantum Writer adalah Metode Quantum Writer merupakan metode Dinike Agustin Puteri, Variasi Bahasa. (91-99) 
yang di dalamnya berisi teknik atau sistem pembelajaran menulis yang terangkum dalam istilah "PAK!". Ungkapan "PAK!" adalah suatu ungkapan yang mewakili sistem empat langkah yang bisa digunakan untuk menjadi Quantum Writer. Sistem PAK! Merupakan suatu cara yang dilakukan untuk memudahkan siswa dalam berlatih menulis yang terdiri atas empat langkah kegiatan, yaitu Pusatkan pikiran(P), Atur(A), Karang(K) dan Hebat (!). (Deporter, 2009:11).

Kegiatan pembelajaran menulis puisi siklus I yang dapat atau ditemukan nilai siswa. Dari 21 siswa, 10 siswa memperoleh nilai diatas KKM (Kriteria Ketuntasan Minimal), sedangkan 11 siswa masih dibawah KKM (Kriteria Ketuntasan Minimal). Hasilnya menunjukkan adanya peningkatan nilai siswa dengan sebelum tindakan dilakukan. Kesulitan siswa dalam menulis puisi diantaranya, siswa kurang mampu memilih diksi yang tepat dalam menulis puisi, terdapat pula siswa yang tidak bisa menyesuaikan judul dengan tema yang diberikan oleh guru, kreativitas siswa dalam mengolah kata - kata pun masih cukup rendah, dan keterampilan mereka dalam menulis masih cukup rendah, kebanyakan dari siswa tidak memperhatikan tulisan dan ejaan yang benar.

Penilaian afektif siswa yang meliputi motivasi, kreativitas, disiplin, dan keberanian dapat terlihat penilaian dari masing - masing aspek. Pada siklus I tahap pasca menulis, semua aspek penilaian afektif yang diberikan

Dinike Agustin Puteri, Variasi Bahasa ternyata menunjukkan hasil bahwa siswa kurang termotivasi dalam proses saat menulis, siswa juga kurang kreatif dan kurang berani untuk memberikan jawaban pada pertanyaan yang diajukan guru, dan siswa kurang disiplin terlihat dari beberapa siswa yang tidak mematuhi intruksi dari guru.

Penilaian produk pada tahap pasca menulis meliputi penilaian terhadap berupa hasil penilaian aktivitas pasca menulis yang meliputi: adalah mendeklamasikan puisi hasil tulisan siswa, mengomentari puisi siswa, dan merevisi puisi berdasarkan pendapat teman.

Dari siklus I disimpulkan bahwa siswa yang mendapat nilai cukup dalam aspek membacakan puisi ada 2 siswa, hal ini karena siswa tersebut merasa malu untuk mendeklamasikan puisinya. Siswa yang mendapat nilai cukup pada aspek memberi komentar ada 2 siswa, hal ini karena siswa tersebut tidak mengetahui apa kekurangan dari puisi temannya, dan siswa yang mendapat nilai cukup dari aspek merevisi puisi ada 6 siswa, hal ini karena siswa merasa bingung dengan hasil komentar temannya.

Perencanaan pada siklus II untuk memperbaiki pembelajaran menulis puisi sebelumnya pada siklus I dengan mengadakan interaksi dengan siswa secara aktif, menumbuhkan rasa percaya diri pada diri siswa. Perencanaan pada siklus II dilakukan berdasarkan hasil refleksi pada siklus I. Oleh karena itu, perencanaan pada 
siklus II ini sudah mengalami perubahan.

Tabel 1 Perbedaan Perlakuan Siklus I dan Siklus II

\begin{tabular}{|c|c|c|c|c|}
\hline $\begin{array}{l}\mathbf{N} \\
\mathbf{0}\end{array}$ & Siklus I & $\begin{array}{c}\text { Kelemahan\& } \\
\text { Kelebihan }\end{array}$ & Siklus II & $\begin{array}{c}\text { Kelemahan\& } \\
\text { Kelebihan }\end{array}$ \\
\hline 1. & $\begin{array}{l}\text { Memperguna } \\
\text { kan media } \\
\text { papan tulis } \\
\text { untuk } \\
\text { menjelaskan } \\
\text { metode }\end{array}$ & $\begin{array}{l}\text { Kelemahan } \\
\text { Siklus I } \\
\text { Penyajian } \\
\text { materi } \\
\text { kurang } \\
\text { menarik }\end{array}$ & $\begin{array}{l}\text { Mempergunaka } \\
\mathrm{n} \text { media karton } \\
\text { berpola dalam } \\
\text { menjelaskan } \\
\text { metode }\end{array}$ & $\begin{array}{l}\frac{\text { Kelemahan }}{\text { Siklus II }} \\
\text { Gambar yang } \\
\text { ditampilkan } \\
\text { kepada siswa } \\
\text { ukurannya }\end{array}$ \\
\hline 2. & $\begin{array}{l}\text { Siswa duduk } \\
\text { tidak } \\
\text { berpasangan }\end{array}$ & $\begin{array}{l}\text { karena guru } \\
\text { hanya } \\
\text { memperguna }\end{array}$ & $\begin{array}{l}\text { Siswaduduk } \\
\text { berpasangan }\end{array}$ & $\begin{array}{c}\text { kurang besar } \\
\text { Kelebihan Siklus } \\
\text { II }\end{array}$ \\
\hline 3. & $\begin{array}{l}\text { Guru tidak } \\
\text { memberikan } \\
\text { reward }\end{array}$ & $\begin{array}{l}\text { kan media } \\
\text { papan tulis } \\
\text { Guru kurang } \\
\text { mampu } \\
\text { memberikan } \\
\text { motivasi } \\
\text { untuk siswa } \\
\text { Siswa }\end{array}$ & $\begin{array}{l}\text { Guru banyak } \\
\text { memberikan } \\
\text { reward/penghar } \\
\text { gaan/poin yang } \\
\text { nantinya } \\
\text { digunakan guru } \\
\text { dalam nilai } \\
\text { afektif siswa }\end{array}$ & $\begin{array}{l}\text { Siswa lebih } \\
\text { mudah untuk } \\
\text { memahami } \\
\text { materi yang } \\
\text { disampaikan } \\
\text { Siswa lebih } \\
\text { mudah untuk } \\
\text { mengamati }\end{array}$ \\
\hline 4. & $\begin{array}{l}\text { Hanya } \\
\text { menampilkan } \\
\text { gambar } \\
\text { sekilas }\end{array}$ & $\begin{array}{l}\text { kesulitan } \\
\text { untuk } \\
\text { menyebutka } \\
\text { n isi gambar, } \\
\text { karena }\end{array}$ & $\begin{array}{l}\text { Menyajikan dan } \\
\text { membagikan } \\
\text { gambar satu } \\
\text { per satu kepada } \\
\text { siswa }\end{array}$ & $\begin{array}{l}\text { gambar, } \\
\text { karena } \\
\text { gambar } \\
\text { dibagikan } \\
\text { satu persatu }\end{array}$ \\
\hline 5. & $\begin{array}{l}\text { Mengerjakan } \\
\text { tugas di buku } \\
\text { kerja siswa } \\
\text { sendiri }\end{array}$ & $\begin{array}{l}\text { gambar } \\
\text { hanya } \\
\text { ditampilkan } \\
\text { sekilas }\end{array}$ & $\begin{array}{l}\text { Guru } \\
\text { menyiapkan } \\
\text { lembar kerja } \\
\text { siswa }\end{array}$ & $\begin{array}{l}\text { kepada siswa } \\
\text { Siswa merasa } \\
\text { lebih mudah } \\
\text { menulis puisi }\end{array}$ \\
\hline 6. & $\begin{array}{l}\text { Memberikan } \\
\text { gambar } \\
\text { dengan tema } \\
\text { lingkungan }\end{array}$ & $\begin{array}{l}\frac{\text { Kelebihan }}{\text { Siklus I }} \\
\text { Siswa cukup } \\
\text { antusias } \\
\text { dengan } \\
\text { penerapan } \\
\text { metode } \\
\text { Quantum } \\
\text { Writer }\end{array}$ & $\begin{array}{l}\text { Memberikan } \\
\text { gambar dengan } \\
\text { tema sekolahku }\end{array}$ & $\begin{array}{l}\text { dengan tema } \\
\text { "sekolahku", } \\
\text { karena objek } \\
\text { itu mudah } \\
\text { diamati. }\end{array}$ \\
\hline
\end{tabular}


Dari tabel, penilaian afektif siswa yang meliputi motivasi, kreativitas, disiplin, dan keberanian dapat terlihat penilaian dari masing - masing aspek. Pada siklus II tahap Pra menulis, semua aspek penilaian afektif yang diberikan ternyata menunjukkan hasil yang lebih baik dari siklus sebelumnya, pada siklus II ini siswa lebih terlihat semangat dan termotivasi untuk belajar. Pada siklus II ini terdapat 2 siswa yang masih kurang berani untuk mengeluarkan daya kreativitasnya, mereka masih terkesan malu - malu. Aspek disiplin dan keberanian siswa pun semakin meningkat baik, hal ini terlihat dengan tidak adanya sikap siswa yang tertib selama proses pembelajaran, siswa juga mulai berani untuk bertanya dan menjawab pertanyaan guru.

Kegiatan pembelajaran menulis puisi siklus II, rata - rata siswa memperoleh nilai B (Baik), dengan rata - rata 80 . Dari 21 siswa, 7 siswa memperoleh nilai A dengan nilai di atas KKM (Kriteria Ketuntasan Minimal), 2 siswa memperoleh nilai $\mathrm{C}$ di bawah KKM (Kriteria Ketuntasan Minimal), dan 12 siswa memperoleh nilai B diatas KKM (Kriteria Ketuntasan Minimal). Hasil tersebut meningkat dibandingkan dengan siklus I dan Pra Tindakan. Siswa yang memperoleh nilai $C$, artinya mereka yang memperoleh nilai di bawah KKM , rata - rata penyebabnya adalah mereka kurang mampu untuk menulis yang rapi dan memilih diksi. Dari tabel terlihat peningkatan dari siklus I ke siklus II.

Dari tabel dapat disimpulkan bahwa tahap pasca menulis pada Dinike Agustin Puteri, Variasi Bahasa (91-99) penilaian produk yang meliputi penilaian terhadap pembacaan puisi, memberi komentar pada puisi teman, dan merevisi hasil komentar teman. Pada aspek membacakan puisi, siswa lebih berani untuk mengekspresikan diri mereka dan tidak malu - malu lagi. Pada aspek mengomentari hasil puisi teman, siswa sudah mampu untuk mengungkapkan apa yang ada dipikiran mereka. Dan aspek merevisi dari hasil komentar teman, siswa sudah mampu memahami maksud komentar yang diberikan temannya, dan ini memudahkan mereka untuk merevisi tulisan mereka.

\section{SIMPULAN}

Berdasarkan hasil observasi sebelum penentuan tindakan, peneliti menemukan salah satu permasalahan yang dihadapi dalam pembelajaran bahasa Indonesia di sekolah, yaitu rendahnya keterampilan menulis puisi. Hal itu terlihat dari rendahnya kualitas menulis puisi yang dihasilkan siswa. Dari kenyataan tersebut peneliti mencoba menerapkan metode Quantum Writer untuk membantu siswa lebih mudah menulis. Pada proses pembelajaran menulis puisi tahap pra menulis dengan metode Quantum Writer pada siswa SMK Telekomunikasi Darul'Ulum, terdapat penilaian proses pada siklus II mengalami peningkatan yang lebih baik dibandingkan dengan siklus I, siswa menjadi lebih disiplin, berani, kreatif, dan termotivasi. Sedangkan penilaian produknya terlihat bahwa pada siklus II siswa lebih lancar 
dalam menentukan tema berdasarkan gambar dibandingkan dengan siklus I.

Pada proses pembelajaran menulis puisi tahap saat menulis dengan metode Quantum Writer pada siswa SMK Telekomunikasi Darul'Ulum, terdapat penilaian proses pada siklus II mengalami peningkatan yang lebih baik dibandingkan dengan siklus I, siswa menjadi lebih disiplin, berani, kreatif, dan termotivasi. Sedangkan penilaian produknya, terlihat dari hasil menulis puisi siswa pada siklus II yang mendapat nilai rata - rata 80, dengan siswa yang memperoleh nilai $C$ (cukup) hanya dua siswa, hasil ini lebih baik jika dibandingkan dengan siklus I yang hanya mendapat nilai rata - rata 70 , dengan siswa yang memperoleh nilai $\mathrm{C}$ (Cukup) mencapai 11 siswa.

Pada proses pembelajaran menulis puisi tahap pasca menulis dengan metode Quantum Writer pada siswa SMK Telekomunikasi Darul'Ulum, terdapat penialaian proses pada siklus II mengalami peningkatan yang lebih baik dibandingkan dengan siklus I, siswa menjadi lebih disiplin, berani, kreatif, dan termotivasi. Sedangkan penialain produk, yang meliputi aspek penilaian membacakan puisi, memberikan komentar terhadap puisi teman, dan merevisi puisi berdasarkan komentar teman, siswa lebih berani untuk membacakan puisi, memberikan komentar pada puisi teman, dan lebih tepat untuk merevisi puisi hasil komentar teman dibandingkan dengan siklus I.

\section{DAFTAR PUSTAKA}

Deporter, Boby. 2009.Quantum

Writer.Bandung:Kaifa

Hamalik, Oemar.2008. Perencanaan

Pengajaran Berdasarkan Pendekatan

Sistem. Jakarta:PT Bumi Aksara

Hernowo. 2009. Mengikat Makna.

Bandung:Kaifa

Sardiman. 2007. Interaksi dan Motivasi Belajar Mengajar. Jakarta:PT Raja Grafindo Persada

Susili, Herawati, Chotimah, Khusnul\&Dwita, Yuyun Sari. 2009.Penelitian Tindakan Kelas. Malang:Bayu Media

Tarigan, Henry Guntur. 2015. Menulis sebagai Suatu Keterampilan Bahasa. Bandung:Angkasa

Tarigan, Henry Guntur.2011.Prinsipprinsip Dasar Sastra.Bandung:Angkasa 